\title{
Qinghai Lake Basin Wetland Landscape Pattern Changes and Driving Force Analysis
}

\author{
Suxu, Chenkelong * \\ College of Biology \& Geography Science, Qinghai \\ Province Key Laboratory of Physical Geography and \\ Environmental Process \\ Qinghai Normal University, \\ Xining, China \\ Xusu8527972@126.com \\ Lubaoliang, Zhangtao \\ College of Biology \& Geography Science \\ Qinghai Normal University,Xining, China \\ w-w987@163.com
}

\author{
Chenliang, Wangjiming \\ CAS key Laboratory salt lake resource and chemistry, \\ Qinghai Institute of Salt Lake, Chinese Academy of \\ Sciences \\ Xining, China \\ Mambo.cl@Gmail.com
}

Jianggang, Wangna

College of Biology \& Geography Science

Qinghai Normal University,

Xining, China

271732900@163.com

\begin{abstract}
With the support of RS and GIS Technology, take 1987, 2000 and 2010's TM remote sensing images as the data source,use the man-machine interactive visual interpretation method to obtain data of Qinghai Lake watershed wetland landscape,_according to the theory of landscape ecology, selection of landscape fragmentation and landscape fractal dimension, analysis of wetland landscape pattern change in Qinghai Lake watershed quantitatively. The results show, (1)the main Alpine swamp of Qinghai Lake is watershed wetland landscape.(2)Qinghai Lake watershed wetland landscape area fluctuates obviously, Changes the landscape structure. (3)1987 2000 wetland landscape area gradually decreased rapidly, Landscape fragmentation and landscape fractal dimension increased significantly. (4)2000 2010 years of wetland landscape area increased rapidly, the fragmentation of the landscape is significantly reduced, the landscape of polymerization degree enhancement.
\end{abstract}

Keywords-Landscape patter; GIS; Qinghai Lake Basin; Drive factor

\section{INTRODUCTION}

According to the definition of the International Convention on Wetlands, Wetland refers to natural or artificial formation of swamp with static or flowing water into shallow water area, also included in the low tide when the water depth of not more than 6 meters of water, with Forests, oceans said the three major global ecological system. It is one kind of different from water, different from terrestrial ecosystem too, an important area as aquatic, terrestrial ecosystem interface extending, is one of the richest biodiversity and ecological landscape and the most important living environment of mankind [1]. Landscape spatial pattern is refers to the landscape patches of different sizes and shapes in space arrangement, it is an important manifestation of landscape heterogeneity, and is the result of various ecological processes on different scales. The wetland landscape pattern depends on the geographical distribution of wetland resources and components, and the ability of anti-jamming, stability, resilience, biodiversity is closely related to wetland ecological system. At the same time, the wetland landscape pattern is not immutable and frozen, the present pattern is formed on the basis of past landscape flow [2]. In recent years, along with the destruction of wetland resources by human activities, landscape ecology wetland has become a hot area of current research [3].

\section{STUDY AREA}

Qinghai Lake basin is located in the northeast of Qinghai province, between $36^{\circ} 15^{\prime} \sim 38^{\circ} 20^{\prime} \mathrm{N}, 97^{\circ} 50^{\prime} \sim 101^{\circ} 22^{\prime} \mathrm{E}$. It is a closed inland basin surrounded by mountains, area $29660 \mathrm{~km} 2$ altitude range of 3194 to $5174 \mathrm{~m}$, the climate is a plateau continental climate, with an average annual temperature of between $-0.80^{\circ} \mathrm{C}$ to $1.10^{\circ} \mathrm{C}$, annual rainfall of $412.80 \mathrm{~mm} \sim 324.50 \mathrm{~mm}$ between annual evaporation capacity of $1502 \mathrm{~mm}$, the seasonal variation of the precipitation, mostly concentrated in the May to September and hot rainy season. Administrative regions mainly include Haibei the Tibetan Autonomous Gangcha County the Ji Ermeng Town, Quanji Town, Yikewulan Town, Shaliu river Town, Haergai Town and triangular city stud farm, the Qinghai Lake Farm, Huangyu Farm, Haiyan County Qinghaihu Town, Ganzi river town, Tuole Town, Jintan Tanxiang, triangle town and public pastures and special land, the Xinyuan Town the Jianghe Town, wooden town, Zhou Qun Township, weaving together Mary Township, fast Erma Township, Yang Kang township, Sullivan Township, Longmen Hill Township, students cell Township Haixi Mongolian-Tibetan Autonomous Prefecture tianjun County town, , Hainan Tibetan Autonomous County Republican town daotanghe, Jiangxi Gou Xiang, dark horse Township, Shi Hai Township, Tong wood frame town and Lake East stud farm, the iron Bojia grassland improvement Experiment Station, a total of 130 administrative villages (70 of 60 inter-basin basin), here is one of the earlier human 
activities in Qinghai Province, also in Qinghai Province is an important animal husbandry production base.

\section{RESEARCH METHODS}

The track number the p132 r35 p133 r34 p133 r35 p134 r34 Landsat-5 TM $(30 \mathrm{~m} \times 30 \mathrm{~m})$ data imaging time for the 1987, 2000 and 2010, each of June, July and August. Use Ground control points (GCP Ground Control Point), polynomial resampling geometric precision correction of remote sensing images of the study area, the error control in the treatment of a pixel, after the image mosaic and projection transformation, the wetlands of the study area is divided into alpine swamp, valley swamps, lakeside wetlands three wetland landscape types cross each other on the basis of the man-machine.

Image enhancement, geometric correction, color composite, crop the image pre-processing on a basin-time image data and by using the ERDAS IMAGE9.3 remote sensing image processing system. Establish Qinghai Lake basin wetland landscape types of remote sensing image interpretation signs according to the spatial resolution of the remote sensing data, the types of wetlands readable, results of previous studies, combined with field site observation and related information.

TABLE I. INTERPRETATION SIGNS OF WETLAND LANDSCAPE TYPE

\begin{tabular}{|c|c|c|c|}
\hline \multirow{3}{*}{ Swamp } & $\begin{array}{l}\text { Alpine } \\
\text { swamp }\end{array}$ & 8 & $\begin{array}{l}\text { Multi-grayish green, } \\
\text { distributed in to the river } \\
\text { valley of the high-altitude, } \\
\text { shady slope, or mountain } \\
\text { hilly Ogaki }\end{array}$ \\
\hline & $\begin{array}{l}\text { Valley } \\
\text { swamp }\end{array}$ & 9 & Form natural bent, Banded. \\
\hline & $\begin{array}{l}\text { Lakeside } \\
\text { swamp }\end{array}$ & 10 & $\begin{array}{c}\text { Dark green, dark green color, } \\
\text { distributed around } \\
\text { the lake or river estuary }\end{array}$ \\
\hline
\end{tabular}

In ArcGIS9.0 Arcedit man-machine interactive interpretation of interpretation according to the established interpretation signs; using GPS precision survey validation outside the industry; edit and modify the resulting data in ArcInfo Workstation environment, main Patch Analyst3. The 2 and Fragstats 3.3 software calculated from the three levels of plaque type and landscape wetland landscape pattern index, interpreted in 1987, three periods 2000 and 2010, the Qinghai Lake basin wetland landscape types of dynamic change.

\section{THE RESUlTS}

We could see from Table 2, From 1987 to 2010 there is first wetlands landscape types in Qinghai Lake Basin, and alpine cold swamp, valleys, swamps, Lakeside marsh landscape type I. Fluctuations in the Qinghai Lake basin of wetland landscape floor area, the landscape structure has undergone some changes. The three of wetland landscape in the largest area are alpine cold swamp, 1987, 2000 and 2010, the area is 1,069.65 square kilometers, 893.79 square kilometers and 1340.33 square kilometers, accounting the overall wetlands $73.93 \%, 77.56 \%$ and $82.94 \%$, this shows that Qinghai Lake basin the main of wetland landscape is alpine cold swamp. Lakeside swamp area attributable to whole of wetland landscape is second place except 1987 , 2000139.79 square kilometers, 148.43 square kilometers in 2010. The accounted of overall wetland landscape area is $12.13 \%$ and $9.18 \%$, respectively, The Lakeside Swamp main located in the place which surrounded by Qinghai Lake, Its floor areas change from Qinghai Lake water. The valley swamp the relative distribution of small wetlands in the Qinghai Lake basin wetlands, 1987 accounted for $13.17 \%$ of the overall wetland landscape area, $10.31 \%$ in 2000. 2010 is $7.88 \%$. The changes in the valley swamp surrounding large rivers flow as well as human activities.

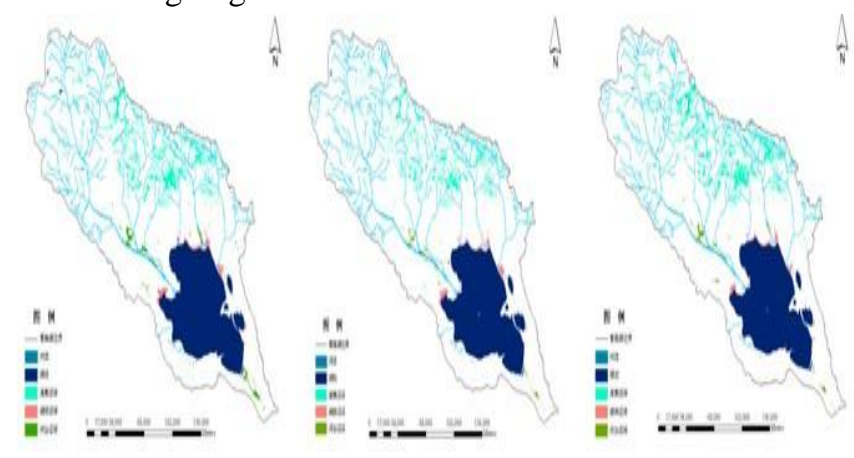

Figure 1. The wetland landscape Of Qinghai Lake Basin (From left to right, 1987, 2000, 2010)

TABLE II.

AREA OF WETLAND LANDSCAPE

\begin{tabular}{|c|c|c|c|}
\hline $\begin{array}{c}\text { Landscape } \\
\text { types }\end{array}$ & $\begin{array}{c}\text { The landscape } \\
\text { area of } 1987 / \mathrm{km} 2\end{array}$ & $\begin{array}{c}\text { The landscape } \\
\text { area of } 2000 / \mathrm{km} 2\end{array}$ & $\begin{array}{c}\text { The landscape } \\
\text { area of } 2010 / \mathrm{km} 2\end{array}$ \\
\hline $\begin{array}{l}\text { alpine cold } \\
\text { swamp }\end{array}$ & 1060.49 & 893.94 & 1340.33 \\
\hline Valley swamp & 189.27 & 118.82 & 127.34 \\
\hline $\begin{array}{l}\text { Lakeside } \\
\text { Wetland }\end{array}$ & 187.88 & 139.79 & 148.43 \\
\hline $\begin{array}{l}\text { All of wetland } \\
\text { landscape }\end{array}$ & 1437.63 & 1152.55 & 1616.10 \\
\hline
\end{tabular}

TABLE III. WETLAND LANDSCAPE INDEX TABLE QINGHAI LAKE BASIN

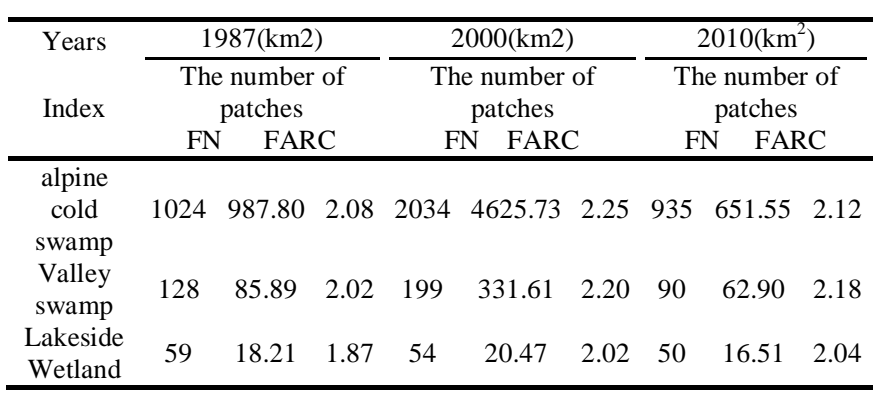

(FN: Landscape fragmentation, units: km2; FARC: Landscape fractal dimension)

We could see from Table 3: The Qinghai Lake basin wetland landscape landscape structure has undergone some changes, from 1987 to 2010. We will divided into two discussion: wetland landscape floor area gradually dwindling rapidly, Which alpine swamp reduce rate for an average annual $12.81 \mathrm{~km} 2$, Valley swamp average annual reduce the $5.41 \mathrm{~km} 2$, Lakeside Swamp average annual 
reduce the $3.69 \mathrm{~km} 2,1987 \sim 2000$. The three landscape fragmentation shows an increasing trend, Increase in wetland landscape area reduction and fragmentation and landscape dimension increases, Have shown that Qinghai Lake Basin climate is gradually warming resulting from changes in vegetation and the human activity is significantly enhanced, exacerbated the fragmentation of the habitats, during this time. The late 2000 to 2010, wetland landscape area increased rapidly, All adds up to 661.2 square kilometers, the average annual increase of 66.12 square kilometers of wetlands, the alpine swamp Range a substantial increase, decade increase of $463.54 \mathrm{~km} 2$, The fragmentation of the landscape significantly reduce, and the degree of landscapes polymerization is enhanced.

\section{DISCUSSION}

The main wetland landscape in Qinghai Lake basin is alpine swamp. Landscape distribution, topography, major rivers and precipitation of the Qinghai Lake basin related to this. Qinghai Lake Basin is located in the Qinghai-Tibet Plateau. Because of its high altitude and rugged terrain, orographic rain is easy to formed. Therefore Peak has accumulated considerable snow and ice. The melting of the snow and ice is an important factor to form the alpine swamp.

Qinghai Lake basin wetland landscape area fluctuates significantly and landscape structure has occurred some changes. Mainly due to wetland landscape of the Qinghai Lake basin large changes in climate, human and other stress factors from $1987-2010$.

Wetland landscape area, from 1987 to 2000, gradually reduce rapidly, landscape fragmentation and landscape fractal dimension is significantly increased. Studies [5] have shown that Qinghai Lake basin appears warm and dry trend from 1987 to 2000 . In this period, environmental becoming warmer and drier result to large range of wetlands reducing. Unreasonable grazing increased within this period of time in the Qinghai Lake basin and residents' awareness of wetland conservation is also relatively weak, which result in the increase of fragmentation of the wetland resources and the reduced area, such as the big change of the daotanghe Valley wetland areaand fragmentation in Qinghai Lake basin. Mainly because of frequent human activities in this area, ong-term grazing as well as the construction of surrounding agricultural landscape, the wetland lose a lot. Lakeside wetlands reduces, especially in the northern and western regions of Qinghai Lake. The main town is close to the wetlands around the Qinghai Lake so a lot of water is used by Human activities, which has influenced the wetlands greatly.

Wetland landscape area and landscape polymerization degree increased rapidly and the degree of fragmentation of the landscape significantly reduced from 2000 to 2010. Qinghai Lake basin became warm and wet gradually [6]. Increases in precipitation and the melting of glaciers have increased wetland water source which resulted in alpine swamp area increased and a significant reduction in the degree of fragmentation of the landscape. Valley wetlands increased $8.52 \mathrm{~km} 2$ in ten years, a lesser extent, which is contrast with the widespread decreases. The main reason for this is change of policy and natural factors and improved man-made ecological awareness of environmental protection. Human factors impacting on wetland landscape fragmentation has been weakened. Lakeside wetlands increase of $8.64 \mathrm{~km} 2$, which is relatively slow, but the overall change is increasing year by year. This is mainly because the lakeside wetlands mostly located in the estuary of several rivers around the Qinghai Lake. Due to the implementation of the ecological measures and the increase in precipitation, the river flow around Qinghai Lake has increased obviously [7], which increased the range of the lakeside wetlands.

\section{ACKNOWLEDGMENT}

This paper is co-sponsored by National Natural Science (41261020, 31260052), the authors would like to thanks to them. And thanks to the anonymous reviewers.

\section{REFERENCES}

[1] KONG Fan ting, XI Min,LI Yue, KONG Fan long, CHEN Wan,et.al.Wetland landscape pattern change based on GIS and RS: A review. Chinese Journal of Applied Ecology, Apr. 2013,24(4): 941946.

[2] Zhang D-S, Lan Z-R , Li Z, et al. Analysis system of spatiotemporal evolution information of the Minjiang River estuary wetlands based on ComGIS. Wetland Science , 2007, 5( 3) : $221-$ 226 ( in Chinese).

[3] YANG Fan, ZHAO Dong-zhi, MA Xiao-feng,WEN Shi-yong, SUO An-ning.The Application of RS and GIS Techniques in Wetland Landscape Ecological Study. Remote sensing technology and application.2007,22(3):471-478.

[4] Chen Kelong, Li Shuangcheng, Zhou Qiaofu, et al. Analyzing Dynamics of Ecosystem Service Values based on Variations of Landscape Patterns in Qinghai Lake Area in Recent 25 Years[J]. Resources Science, 2008(2): 274-280.

[5] YI Wanjuan, LI Xiaoyan, CUI Buli, MA Yujun.Climate Change and Impact on Water Level of the Qinghai Lake Watershed. Journal of Arid Meteorology.2010, 28(4) : 375-383.

[6] CHEN Liang, CHEN Kelong, LIU Baokang, HOU Guangliang, CAO Shengkui, HAN Yanli, YANG Long, WU Yanpeng.Characteristics of Climate Variation in Qinghai Lake Basin During the Recent 50 Years. Journal of Arid Meteorology, 2011, 29(4) : 483- 487.

[7] SUNYong-liang, LI Xiao-yan, TANG Jia, XUHe-ye.Climate Change and Hydrological Response in the Watershed of Qinghai Lake. Resources Science,2008,30(3):354-362. 